\title{
Popular perception of urban transformation through megaevents: understanding support for the 2014 Winter Olympics in Sochi
}

\author{
Müller, Martin
}

\begin{abstract}
With the increasing number and impact of events hosted by cities, understanding the nature of popular support for them and the resulting urban transformations is a crucial task. This paper examines residents' perceptions of the preparations for the 2014 Winter Olympic Games in Sochi, asking how support differs across social groups and what factors predict support. It finds that negative impacts from preparations dominate public opinion, but that there is nevertheless a solid support base for the event. Support tends to be strongest among non-Russians, the younger generation and residents who have good knowledge of the preparations. Perception of positive impacts, in particular expected image improvement, is the strongest predictor of support, while perception of negative impacts shows a much weaker association with support. The paper concludes that delivering on the positive aspects of events might be more important for administrations than minimizing the negative side-effects.
\end{abstract}

DOI: https://doi.org/10.1068/c11185r

Posted at the Zurich Open Repository and Archive, University of Zurich

ZORA URL: https://doi.org/10.5167/uzh-78843

Journal Article

Published Version

Originally published at:

Müller, Martin (2012). Popular perception of urban transformation through megaevents: understanding support for the 2014 Winter Olympics in Sochi. Environment and Planning C: Government and Policy, 30(4):693-711.

DOI: https://doi.org/10.1068/c11185r 


\title{
Popular perception of urban transformation through megaevents: understanding support for the 2014 Winter Olympics in Sochi
}

\author{
Martin Müller \\ Universität St Gallen, Varnbüelstrasse 19, 9000 St Gallen, Switzerland; \\ e-mail:martin@martin-muller.net \\ Received 5 July 2011; in revised form 19 December 2011
}

\begin{abstract}
With the increasing number and impact of events hosted by cities, understanding the nature of popular support for them and the resulting urban transformations is a crucial task. I examine residents' perceptions of the preparations for the 2014 Winter Olympic Games in Sochi, asking how support differs across social groups and what factors predict support. I find that negative impacts from preparations dominate public opinion, but that there is nevertheless a solid support base for the event. Support tends to be strongest among non-Russians, the younger generation, and residents who have good knowledge of the preparations. Perception of positive impacts-in particular, expected image improvement-is the strongest predictor of support, while perception of negative impacts shows a much weaker association with support. I conclude that delivering on the positive aspects of events might be more important for administrations than minimizing the negative side effects.
\end{abstract}

Keywords: megaevents, Olympic Games, impacts, attitudes, perception, support, Russia

\section{Introduction}

Over the past few decades events have become central tools in urban and regional development. Whether it is megaevents such as the Olympic Games or smaller-scale occasions such as local music festivals, it will be hard to find cities and regions not eager to host them. In what Häußermann and Siebel (1993) termed the festivalization of urban politics, events have become a major instrument for cities, not only to compete for attention and raise the public profile but also to attract tourist expenditure and upgrade urban infrastructure (Richards, 2007; Roche, 2000). For the local population large-scale events, in particular, are often a double-edged sword. On the one hand, residents bear the brunt of costs associated with events. These costs can be monetary expenditure, such as rising prices for housing or an increasing tax burden when a city opens its coffers to support and host particular events. But they can also take on nonmonetary forms such as social exclusion and displacement, environmental destruction, or disruption of urban services (eg, Lenskyj, 2002; Waitt, 1999). On the other hand, events can result in increased revenues and urban revitalization and can function as catalysts for upgrades of the urban infrastructure and public services. The inflow of tourist expenditure might result in new jobs and increased tax revenue (Preuss, 2004). Events may be leveraged to regenerate neglected areas and stimulate social development (Smith and Fox, 2007) or act as catalysts for urban sustainability and policy making (Benneworth and Dauncey, 2010; Holden et al, 2008). Improvements in the transport infrastructure or in leisure opportunities, which often accompany events, also accrue to a large majority of residents (Vrijaldenhoven, 2007).

How people perceive the costs and benefits of megaevents is a crucial factor determining support or opposition to the event. The expectation of benefits is likely to buttress support, 
whereas the expectation of negative impacts is likely to produce public dissatisfaction and possibly result in resistance in the form of protests or formal political opposition (Burbank et al, 2000; Lenskyj, 2008, pages 15-76). What is more, costs and benefits might impact social groups in an uneven way: ethnic minorities, for example, might not be able to benefit to the same extent as the majority group (O'Bonsawin, 2010). An understanding of the factors that enhance or undermine support for the preparation of a megaevent and their social differentiation is crucial in any kind of participatory planning on the basis of citizens' input and needs, which is now de rigueur in many countries (Conrad et al, 2011; OECD, 2001). Such an incorporation of public perception in the planning process can act as a counterbalance to the fact that megaevents "tend to be developed largely by undemocratic organisations with autocratic decision-making and a pervasive lack of transparency" (Gotham, 2011, page 210; see also Ponsford and Williams, 2010). It allows addressing the gravest public concerns with the organization of megaevents and reducing the potential of social conflict and disgruntlement and provides a basis for allocating scarce budgetary means and maintaining a climate of cooperation to ensure an efficient preparation for the event. Not getting deadlocked in disputes is all the more important in light of the tight timetable of megaevent preparations: unlike most large-scale construction projects, the opening of megaevents cannot be postponed but has to take place on the preset date no matter the cost.

This contribution seeks to work towards a better understanding of the public perception of the urban impacts from the preparation for megaevents and its relation to public support. For whereas the impacts from megaevents have received significant attention in urban and regional studies, their perception and the resulting implications for city administrations have been rather less studied (Hiller and Wanner, 2011; Zhou and Ap, 2009). This observation is somewhat surprising, given the long-standing emphasis on public involvement in planning (Arnstein, 1969) and the value placed on broad public support and equitable distribution of benefits in events such as the Olympic Games (eg, IOC, 2005). What is more, research has devoted most attention to megaevents in Western Europe and North America, ignoring the recent trend for these events to be hosted in emerging markets such as Brazil and Russia (Lorde et al, 2011, page 350; Zhou and Ap, 2009, page 79). Planning processes in emerging markets, however, often feature a more hierarchical planning culture, less pressure on financial resources, less concern for environmental issues, and more profound urban transformations in a push for modernization than cities in the West (eg, Abramson, 2007; Stanilov, 2007). In an attempt to address these lacunae I extend our purview to the city of Sochi in Russia, host of the 2014 Winter Olympic Games. Drawing on a sample of 604 local residents, I address three main questions:

(1) How do residents perceive the impacts from the preparation for the Olympic Games?

(2) How does support for the Olympic Games differ across social groups?

(3) What aspects of perception have a positive or negative association with support?

\section{Megaevents and their impacts}

\subsection{Differing rationales for hosting megaevents in Western and emerging economies}

Megaevents have become a popular object of research in urban and regional studies in the past two decades (Hiller, 2000). In many Western countries the rise of the event in the urban and regional economy has often been linked to the emergence of an entrepreneurial mode of governance, which sees cities and regions compete for additional income flows and attract tourists and residents as well as investment under intensifying fiscal pressure (Hall and Hubbard, 1996). In what has been termed a shift towards a symbolic urban economy (Lash and Urry, 1994), this constellation promoted the cultivation of images and the development of brands through hosting particular events (Gratton et al, 2005; Paddison, 1993; Richards and Wilson, 2004; Smith, 2005a). With the help of what Andranovich et al (2001) call a 'megaevent 
strategy', cities and regions aim to forge growth coalitions that attract megaevents and position themselves in the competition for capital streams and tourist revenues. The coalitions of actors that come together for hosting a megaevent often give new impulses and coherence to urban and regional governance (Newman, 2007). This enables the realization of projects that may have dragged on for a long time: downtown revitalization, a new underground line, or a new convention centre. Even when bids fail, the thrust of the bidding phase can still act as a catalyst for forming new coalitions that are beneficial for urban development (Benneworth and Dauncey, 2010).

Beginning with the Olympic Games in Beijing 2008, there has been a noticeable shift towards hosting megaevents outside Western Europe and North America. The 2012 European Football Championships in Poland and Ukraine, the Olympic Games in Sochi 2014 and Rio de Janeiro 2016, and the World Cups in South Africa 2010, Brazil 2014, Russia 2018, and Qatar 2022 are but the most prominent exemplars of this trend. There are two major drivers behind this development, one on the bidding side and the other on the selection side. Among bidders the strong growth of emerging markets has created the necessary capital and infrastructure base as well as technical know-how to put together and finance sophisticated applications that meet and exceed the requirements of governing bodies such as the IOC and FIFA. At the same time, owing to the sovereign debt crisis, Western states have become less willing to foot the substantial public bill of megaevents. In the race to host the 2020 Summer Olympic Games, for example, Toronto and Rome have both dropped out citing financial concerns, and the third Western candidate, Madrid, also faces economic and social turmoil. On the selection side, awarding megaevents to emerging countries contributes to opening up new markets with considerable growth potential, which is of particular interest for the corporate sponsors that fund the lion's share of these events. What is more, host cities in these economies often have fewer financial and planning constraints in hosting megaevents.

This geographical shift often coincides with a shift in the rationales for bidding for and hosting such events. No longer is it primarily individual cities on the quest for jobs and investment, but it is also states in search of a platform with which to showcase achievements and signal diplomatic stature (Cornelissen, 2010). The construction and projection of an international image of economic prowess and geopolitical reemergence have been placed centre stage in events such as the Olympic Games in Beijing and Sochi (Berkowitz et al, 2007; Müller, 2011). The symbolic component of place and nation branding for political purposes thus often takes precedence over the more material impacts on growth or infrastructure in these settings.

\subsection{Urban and regional impacts of megaevents}

Whatever the rationale for hosting a megaevent, for local residents it is often a mixed blessing. On the one hand, events and the preparations for them create disruptions to normal life. In the case of megaevents large-scale construction programmes to build venues and accommodation or upgrade the transport infrastructure commonly extend over many years and come with a budget of sometimes several billion euros (Chalkley and Essex, 1999). This type of event often produces major and prolonged impacts for residents that range from noise pollution or traffic jams to irreparable environmental damage, an increased tax burden, or hikes in property prices that precipitate and reinforce gentrification and segregation. Oftentimes, the funds allocated to megaevents benefit privileged elites, while further marginalizing already disadvantaged groups (eg, Gotham, 2011; O’Bonsawin, 2010). Some areas in Sydney, for example, saw significant increases in housing prices and rent levels during the preparation for the Olympic Games, leading to a displacement of disadvantaged populations (Lenskyj, 2002, pages 89-106). In the worst cases residents may face expropriation and relocation if their property is earmarked for megaevent development, as was the case with the Olympic Games 
in Beijing (Wang, 2006). Resistance to megaevents is therefore a common phenomenon and frequently an expression of the dissatisfaction with the uneven outcomes and social exclusion that comes with megaevents (Burbank et al, 2000; Lenskyj, 2008, pages 15-76; O'Bonsawin, 2010).

On the other hand, hosting megaevents may result in tangible benefits to local residents. The amenities of the tourist infrastructure as well as new exhibition halls or sports venues are left as legacies for the population to use a long time after the event has concluded. If planned with foresight, venues can be converted for community use after the event, as happened with the curling and speed-skating venues of the Olympic Winter Games in Vancouver 2010 (Kidd, 2010). An improved transport network results in shorter travel times and more convenient connections. Some megaevents also attempt to leverage the educational and regeneration opportunities arising from the preparation for the event. The Commonwealth Games in Manchester in 2002 are a good example of economic and social regeneration initiatives tied to a megaevent that aimed to improve the skills and competitiveness of the targeted population and enterprises (Smith and Fox, 2007). The Olympic Games in London 2012, too, have at their heart a regeneration plan for the Lower Lea Valley area in East London-among others, enhancing transport and utilities infrastructure and providing affordable housing and indoor and outdoor leisure facilities (MacRury and Poynter, 2008). Finally, the capital flows into the region may create additional jobs and revenue for local businesses and contribute to economic growth (Preuss, 2004). This economic stimulus effect, however, is difficult to calculate and often overestimated (Matheson, 2008), sometimes due to the political interest involved.

In addition to these material changes, hosting a megaevent also has significant effects on the symbolic plane. Megaevents provide a unique communication platform that is recognized not only by sponsors but also by host cities. This platform is often employed to raise the public profile or give the city or national image a makeover by association with the megaevent, and it has therefore become valuable as an image-enhancement tool (Richards and Wilson, 2004; Smith, 2005a; Waitt, 1999). For Torino, for example, the Olympic Winter Games in 2006 were part of a wider place-branding strategy that was to recreate a creative, vibrant, cosmopolitan image of the city as opposed to its reputation as a moribund industrial backwater and home to the crisis-stricken Fiat automotive plants (Vanolo, 2008). Considering the move towards sustainability in the Olympic Games, Holden et al (2008) also speculate that the communicated message of sustainability might well be the most permanent legacy of the Vancouver Olympic Games. Ritchie and Smith (1991), however, show that the impact of megaevents on people's awareness of cities can be rather ephemeral and transient. This finding is echoed in an empirical study of the branding effects of the Olympic Games in Beijing, which concludes that the impacts were short-lived, one-off effects. What is more, the official brand messages did not bear much relationship to how the general public perceived and experienced daily reality in their city, further hampering the credibility of the branding campaign (Zhang and Zhao, 2009). Instead of a panacea, megaevents should thus rather be considered as just one tool in a larger tool box of a long-term strategy of place branding (Smith, 2005b).

\section{Setting the scene: Sochi 2014}

Owing to the large-scale transformations associated with the preparations for the 2014 Olympic Games, residents experience a broad and varied range of both positive and negative transformations. As one commentator describes it:

"The city faces a transformation from a tranquil resort to a megapolis with sports and recreation industry of a global level. This is why many people have to radically change their lives, jobs, everyday practices and household economy" (Klimov, 2010, page 163). 
This situation allows the comparison of the perception of a wide spectrum of impacts. What is more, in the process of planning for the Olympic Games, Sochi exhibits some radical differences from its predecessor Vancouver and other megaevents in Western cities. These concern, in particular, the top-down, dirigiste planning with little community participation, the absence of systematic environmental assessment, and widespread financial profligacy (Müller, 2011; Roux, 2010; Scharr and Steinicke, 2010). The profound transformation and the specificities of the planning process make Sochi a particularly rewarding object for studying the perception of megaevent impacts and their relation to popular support.

Sochi is an urban agglomeration with a population of about 410000 , situated on the shores of the Black Sea where Russia borders the Georgian breakaway republic of Abkhazia. More than $70 \%$ of the population of Sochi is Russian, but there are significant minorities of Armenians (about 15\%) as well as a number of other ethnic groups including Ukrainians, Georgians, and Abkhazians (Goskomstat, 2007). When Sochi won the right to host the 2014 Winter Olympic Games in July 2007, its bid differed from most previous successful applications for the Winter Olympics in that the area lacked most of the infrastructure that is required to host the Games. This applies equally to sports facilities and to general physical infrastructure for transport, energy, and information and communication technology. Snow sports do not have a tradition in the area, and the first chairlift was not built until 1993 (Scharr and Steinicke, 2010). In the same vein, facilities for ice sports are completely absent and need to be built from scratch. The region also suffers from chronic energy shortage and deficient road infrastructure that causes regular traffic jams.

To meet the requirements for an Olympic host, the Russian authorities have launched a massive construction programme that comes with a budget of more than one trillion roubles (about 25 billion euros), or more than 60000 euros per inhabitant of the region. This price tag makes the Sochi Games by far the most expensive Winter Games in Olympic history (Müller, 2011). The significant increase of costs vis-à-vis the previous Winter Olympic hosts Vancouver, Torino, and Salt Lake City can be attributed to the extensive infrastructure development that Sochi needs to undergo. Only about $15 \%$ of the funds are channelled into the construction of sports facilities, whereas almost $60 \%$ are earmarked for improvements in the transport infrastructure. Most of the building activity is scheduled to occur between 2010 and 2013, concentrating the main impact of the preparations in a time period of only about four years.

On the negative side, the building activity has led to a considerable increase in noise and dirt in some parts of the city and has exacerbated the occurrence of traffic jams (Novaja Gazeta 2009). It has been criticized for inflicting substantial environmental damage on the fragile ecosystems of the Caucasus and encroaching on protected areas (Roux, 2010). The need for more than 180000 construction workers for the 242 Olympic objects has also resulted in a sharp jump in inflows of labour migrants, aggravating the housing situation in an already squeezed property market (Ogonëk 2010; Vlast 2008). Speculation has contributed its share to a steep rise in property values that has priced many local residents out of the market, although price inflation was dampened somewhat after the economic crisis in 2008 (Agureeva, 2010; Den'gi 2011).

On the other hand, Sochi stands to benefit from the immense influx of capital from the Russian federal budget. The expected investment is almost a hundred times the annual municipal budget of eleven billion roubles and will result in a wholesale overhaul and modernization of the infrastructure in the region (City Administration of Sochi, 2011). The most palpable improvements are projected to occur in the road and public transport infrastructure as well as the security of energy supply. What is more, the investments will result in a thorough upgrade and extension of the available recreational facilities, turning 
Sochi into a year-round resort (Bidding Committee Sochi, 2006). This investment, in turn, is expected to generate a significant number of long-term jobs, particularly in the tourism industry, which will create additional income for the local population.

The most salient impact at the international level, however, is expected to be the branding effect. Throughout the bidding and preparation phase Vladimir Putin (2007, unpaginated) has repeatedly declared his intention to position Sochi as a world-class resort for summer and winter tourism with a global reputation. In his speech at the 119th session of the IOC in Guatemala in 2007, where Sochi was awarded the right to host the Games, he stated that "Sochi is going to become a new world class resort for the new Russia. And the whole world!" The Winter Olympic Games are meant to provide the cutting-edge skiing infrastructure and high-class accommodation as well as the branding platform to advertise the resort to an international flock of visitors. As such, they serve as an instrument to show to the world that Russia, besides being an energy superpower that likes to flex its military muscle, should also be taken seriously as a global player in the game of leisure and tourism.

\section{Research design}

Whether the costs associated with a megaevent outweigh the benefits or vice versa is a crucial question when it comes to popular support for an event. While the consideration of expert opinion is one component in resolving this question, popular interpretation might well present a distinct picture that is worth considering on its own (cf Kokx and van Kempen, 2010). After all, as the famous Thomas theorem puts it: "if men [sic] define situations as real, they are real in their consequences" (Thomas and Thomas, 1928, pages 571-572). In line with research in cognitive psychology, this study is thus interested not so much in the objective impacts of preparations for the Olympic Games as reflected, for example, in statistics but in their popular perception. The relationship between perception and impacts is not a clearcut one: people might exaggerate some impacts, while not giving attention to others. Since popular perceptions might not match other assessments but commonly serve as the basis for people's actions, it is worth considering them in their own right.

\subsection{Model specification}

This study hypothesized that the perception of positive impacts has a positive effect on support, whereas the perception of negative impacts has a negative effect. The conceptual foundation for this hypothesis can be found in social exchange theory (Ap, 1992). It posits that an actor will be willing to engage in an exchange, such as supporting preparations for a megaevent, if he or she finds the benefits of the exchange to outweigh the costs and thus assumes an instrumental calculation and evaluation to be at the basis of actors' decisionmaking processes. Social exchange theory has been adopted as a framework by a wide range of studies examining perceptions of events in the field of tourism [Gursoy and Kendall (2006), Kim et al (2006), Ritchie et al (2009), and Waitt (2003) are a few more recent examples].

The positive correlation between perceived benefits and support for events and the negative correlation between perceived costs and support has been established in a number of studies [see Deccio and Baloglu (2002) and Gursoy et al (2002) for good overviews]. In the present study I extended existing research through incorporating two principal modifications that are relevant to the case of Sochi. First, I added two control variables that were expected to moderate the effect of perceptions on support (Gursoy and Kendall, 2006, page 619). One is the level of knowledge about the event; the second is the degree of people's involvement in the planning process. If people feel left out of the preparation for an event and are presented with projects as faits accomplis that cannot be altered, support is likely to be dampened (Fredline and Faulkner, 2002; Lankford and Howard, 1994; Simmons, 1994). After all, it is local residents who will have to live with the results of planning decisions. A first step in 
participation is ensuring adequate knowledge levels about event planning. Keeping residents informed is an important component in maintaining support, since a lack of information is frequently associated with negative attitudes (Davis et al, 1988; Keogh, 1990; Lankford and Howard, 1994). Entering into dialogue with local residents and disseminating information about Olympic planning are even more important in the case of Sochi, where communication and exchange of information between citizens and the city administration are close to nonexistent and there is widespread mutual distrust (Klimov, 2010, page 168).

Second, I took up Kim and Petrick's (2005) suggestion to pay greater attention to sociodemographic factors in shaping support of events. This is of particular importance in Sochi with its multiethnic population. Light (2010) observes, for example, that in the course of the preparation for the Olympic Games in Sochi members from ethnic minorities have come under pressure and might be edged out of the tourism business to make way for larger corporate investors. If benefits and burden are perceived to be distributed unevenly across ethnicities, ethnic affiliation may impact on levels of support.

\subsection{Variable measurement}

To measure the popular perception of impacts and how it affects support for the Olympic Games, I aimed to develop two scales, one reflecting possible positive and the other possible negative perceptions. An initial pool of twenty-nine items was generated from a review of the pertinent literature on the perception of event impacts from the field of tourism and event studies (Delamere, 2001; Delamere et al, 2001; Fredline et al, 2003; Kim et al, 2006). The list of items was then discussed with residents of Sochi and local scholars to gauge its content validity and completeness and ensure the relevance of the scale items (Delamere et al, 2001, page 18). As a result, several items were removed and two were added: one probing the perception of elite capture ("The preparation for the Olympic Games makes a few rich and the others have little benefit") and a second one examining the changes in energy security ("... leads to a modernization of the energy supply"). A pretest with twenty-seven university students provided feedback on the comprehensibility and clarity of the questionnaire. The final list comprised twenty-three items, thirteen for the positive perception scale and ten for the negative perception scale, and is shown in figure 1 . All items were assessed on a five-point Likert scale.

Support as the dependent variable was also measured on a five-point Likert scale using the phrasing of Mihalik and Simonetta (1999), who asked respondents whether they considered it a good idea overall to host the Olympic Games in their city. Citizen participation was also assessed on a five-point Likert scale, expressing agreement or disagreement with the statement "The preparations for the Olympic Games are carried out without consulting local residents." Knowledge about the preparations was self-rated and could be scored on a five-point scale.

\subsection{Data collection}

Questionnaires were administered face-to-face in situ in six locations in Sochi (the seaside promenade, a block of several commercial streets, a recreational park, the central market, near the train station, and one residential area) on 4-7 November 2010. The time period included a public holiday and a weekend to ensure that a broad sample of residents could be met on the streets. University students were trained to conduct the survey and monitored on survey days to ensure consistency in interviewing. Interviewers were instructed to intercept every third passer-by, explain the purpose and scope of the survey, and solicit their participation. Some 856 contacts resulted in 619 completed questionnaires (rejection rate $=27.7 \%$ ), of which 604 were usable for further analysis $(N=604)$. 


\subsection{Data preparation}

Before analysis, data were analyzed for distribution and collinearity. Skewness and kurtosis scores for the large majority of variables were between -1 and 1, and normal probability plots did not suggest strong deviations from the normal distribution. Scores outside the interval $[-2 ; 2]$ and thus outside the commonly acceptable range for psychometric studies were found only for the perception items on traffic jams ( and immigration (skewness $=-1.11$, kurtosis $=3.13$ ). The absence of low scores in both cases truncates correlations with other variables. Collinearity diagnostics indicated that multicollinearity was not an issue (tolerance levels at or above 0.5 and variance inflation factor at or below 2.0 for all predictors).

\subsection{Methods of data analysis}

We used the $t$-test to determine differences in support between groups with different sociodemographic characteristics. The unidimensionality of the two scales was assessed through principal components factor analysis with an eigenvalue cut-off of 2 . Items were required to have higher loadings on their construct than on other constructs and to surpass a loading of 0.4 to be retained. The internal consistency of the positive and negative scales was then examined using Cronbach's $\alpha$, where values above 0.7 are commonly considered acceptable and above 0.8 are considered good (Cortina, 1993; Nunnaly, 1978). The analysis then implemented the recommendation of Ritchie et al (2009) to construct a step-wise multiple regression model that examines the contribution of individual predictors to explaining support. Adjusted $R^{2}$ was employed to compare the models for their explanatory value.

\section{Results}

\subsection{Respondent characteristics and differences in support}

The sample showed a balanced split between female and male respondents and adequate representation of minority groups (table 1). Self-rated knowledge of the preparations for the Olympic Games followed almost a normal distribution, with an average knowledge score of

Table 1. Respondent characteristics.

\begin{tabular}{lclc}
\hline & Percentage & Percentage \\
\hline Gender & & Knowledge & \\
Female & 52.9 & Very poor & 5.7 \\
Male & 47.1 & Poor & 25.9 \\
Age & & Medium & 426. \\
$16-29$ & 28.0 & High & 21.2 \\
$30-39$ & 21.0 & Very high & 4.7 \\
40-49 & 23.4 & Participation & \\
$50-59$ & 12.8 & Very low & 36.5 \\
$\geq 60$ & 14.8 & Low & 42.9 \\
Education & & Medium & 12.7 \\
Higher & 43.1 & High & 6.9 \\
Unfinished higher & 25.4 & Very high & 1.0 \\
High school professional & 21.5 & Support & \\
High school & 8.3 & Strongly disease & 6.4 \\
None & 1.7 & Disagree & 12.6 \\
Ethnicity & & Undecided & 24.0 \\
Russian & 57.0 & Agree & 41.7 \\
Armenian & Strongly agree & 15.3 \\
Georgian & & & \\
Other & 7.5 & & \\
\hline
\end{tabular}


-0.1 (on a range from -2 to 2 ; $\mathrm{SD}=0.94$ ). Fewer than $8.0 \%$ of respondents said that local residents were consulted in the preparations for the event. Nevertheless, $57.0 \%$ supported the idea of hosting the Olympic Games in Sochi, whereas only 19.0\% rejected it. The mean support score across the sample was 0.47 (on a range from -2 to $2 ; \mathrm{SD}=1.09$ ), indicating moderate support.

Table 2 shows that there were significant differences in levels of support between social groups. The most striking difference was found between respondents with a high level of knowledge and those with a low level of knowledge, where high levels of knowledge were associated with more enthusiasm about welcoming the Olympic Games. Non-Russian ethnic minorities also showed higher levels of approval than Russians, and younger respondents held more favourable views than the age group above 60 . If respondents perceived that participation in the planning and preparation process was high, this coincided with a significantly higher approval rating. Differences between male and female respondents were marginally above the significance threshold, with men being more favourably disposed towards the Olympic Games than women. Although there are significant differences in support, on average none of the social groups examined rejected the idea of having the Olympic Games in Sochi.

Table 2. Mean differences in support for the Olympic Games in Sochi.

\begin{tabular}{|c|c|c|c|c|}
\hline & Support (mean score) & & $t$ & df \\
\hline \multirow[t]{2}{*}{ Russian ethnicity } & Russian & Non-Russian & & \\
\hline & 0.39 & 0.62 & $-2.50 *$ & 566 \\
\hline \multirow{2}{*}{ knowledge } & high $^{\mathrm{a}}$ & low ${ }^{\mathrm{b}}$ & & \\
\hline & 0.95 & 0.29 & $6.05 * *$ & 322 \\
\hline \multirow[t]{2}{*}{ participation } & $\operatorname{high}^{\mathrm{a}}$ & low ${ }^{\mathrm{b}}$ & & \\
\hline & 0.81 & 0.36 & $2.54^{*}$ & 491 \\
\hline \multirow[t]{2}{*}{ age } & $16-29$ & $\geq 60$ & & \\
\hline & 0.62 & 0.29 & $2.30^{*}$ & 247 \\
\hline \multirow[t]{2}{*}{ gender } & female & male & & \\
\hline & 0.39 & 0.57 & -1.93 & 562 \\
\hline \multicolumn{5}{|c|}{$* p<0.05 ; * * p<0.01$} \\
\hline \multicolumn{5}{|c|}{$\begin{array}{l}\text { Note: Mean support score is on a five-point Likert scale where }-2 \text { is lowest and } 2 \text { is highest. } \\
\text { a Combines the two highest values on the five-point Likert scale. } \\
{ }^{b} \text { Combines the two lowest values on the five-point Likert scale. }\end{array}$} \\
\hline
\end{tabular}

\subsection{Perception of impacts}

When asked about their perceptions of impacts, respondents agreed about the presence of almost every impact - both positive and negative - except for personal benefit (figure 1). The occurrence of additional traffic jams as well as price increases in housing as well as food and services received the highest agreement rating among negative impacts. Among positive impacts, people found the improvement of Sochi's global image most applicable, followed by enhanced opportunities for shopping and entertainment and the promotion of economic growth. Respondents tended to rank those positive impacts that accrue at the individual level towards the bottom. In particular, people disagreed that they received any immediate personal benefit from the preparations for the Olympic Games. On average, there was also little optimism about the prospect of jobs for the local population. The high standard deviation for this item indicates, however, that opinion was rather divided: more than $42 \%$ agreed with that statement, while $35 \%$ disagreed.

Principal components factor analysis with the criteria detailed above suggested dropping one factor from the positive scale (“... creates opportunities for shopping and entertainment”) 


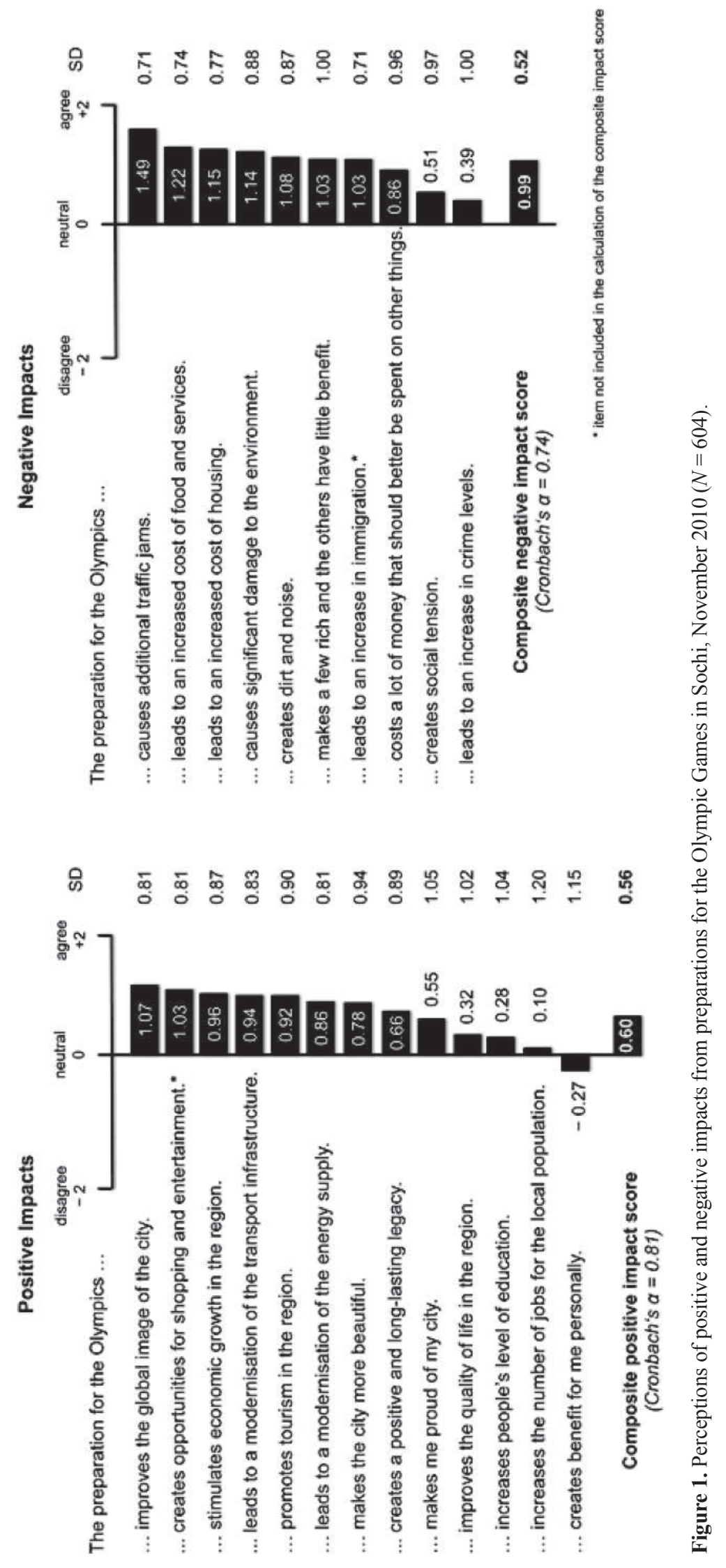


and one factor from the negative scale (“... leads to an increase in immigration") to obtain unidimensionality. Reliability analysis for the items in the trimmed scales indicated internal consistency with acceptable or good values of Cronbach's $\alpha$ (figure 1). At 0.99, the composite score of the negative impact scale was significantly higher than that of the positive impact scale (score: $0.60 ; t=-11.3, p<0.01$ ). Respondents showed strong agreement $(\geq 1.0)$ with seven of the ten negative impact items, while the same was true for only two of the thirteen positive impact items.

\subsection{Predictors of support}

In order to identify and compare the explanatory value of the predictors of support, I ran three regression models. The results are reported in table 3. Model 1 included only the scores from the two trimmed impact scales as predictors. It explained a high proportion of the variance of support (adjusted $R^{2}=0.36$ ), with positive perceptions having a strong positive impact on support $(b=0.53)$, whereas negative perceptions had a moderate negative impact on support $(b=-0.18)$. Model 2 added the three control variables knowledge, participation, and Russian ethnicity, which were hypothesized to moderate support. Higher knowledge had a weak positive association with support $(b=0.10)$, but Russian ethnicity and participation did not enter the model below the significance threshold. Adding gender, education, and age in model 3 resulted in a slight improvement of the proportion of variance explained and produced male gender and lower educational achievement as significant predictors of support $(b=0.09)$.

In a second step I aimed at isolating the facets of negative and positive impacts that predicted support. For this purpose I ran a regression model with the twenty-three individual items of the decomposed scales. Table 4 reports the results for predictors below the 0.05 significance level. The proportion of the variance explained is high (adjusted $\left.R^{2}=0.46\right)$, and, as the results from above suggest, positive perception items showed the strongest associations with support. Improvement of Sochi's global image $(b=0.28)$ and civic pride $(b=0.17)$ were the best positive predictors, with personal benefit $(b=0.15)$ coming in third. Perceived damage to the environment $(b=-0.10)$ and waste of public resources $(b=-0.10)$ entered as the strongest negative predictors.

Table 3. Predicting support for the Olympic Games in Sochi $(n=558)$.

\begin{tabular}{lccc}
\hline & \multicolumn{3}{c}{ Support (standardized $\beta$ coefficient $b$ ) } \\
\cline { 2 - 4 } & model 1 & model 2 & model 3 \\
\hline Positive perception score & $0.53^{* *}$ & $0.50^{* *}$ & $0.50^{* *}$ \\
Negative perception score & $-0.18^{* *}$ & $-0.15^{* *}$ & $-0.15^{* *}$ \\
knowledge & & $0.10^{* *}$ & $0.11^{* *}$ \\
participation & & -0.05 & -0.05 \\
Russian ethnicity & -0.03 & -0.01 \\
education & & & $-0.07^{*}$ \\
age & & & -0.05 \\
gender-male & & $0.07^{*}$ \\
Adjusted $R^{2}$ & 0.36 & 0.37 & 0.38 \\
$F$ & $158.2^{* *}$ & $66.5^{* *}$ & $43.3^{* *}$ \\
$* p<0.05 ; * * p<0.01$. & & & \\
\hline
\end{tabular}


Table 4. Predicting support for the Olympic Games in Sochi from aspects of the perception of Olympic Games preparation (only significant predictors shown) $(N=493)$.

\begin{tabular}{lc}
\hline & Support (standardized $\beta$, coefficient $b)$ \\
\hline Image improvement & $0.28^{* *}$ \\
Civic pride & $0.17^{* *}$ \\
Personal benefit & $0.15^{* *}$ \\
Positive legacy & $0.11^{* *}$ \\
Promotion of economic growth & $0.11^{* *}$ \\
Environmental damage & $-0.10^{*}$ \\
Waste of public resources & $-0.10^{* *}$ \\
Increase in crime & $-0.09^{*}$ \\
Adjusted $R^{2}$ & 0.46 \\
$F$ & $18.9^{* *}$ \\
$* p<0.05, * * p<0.01$. & \\
\hline
\end{tabular}

\section{Discussion}

\subsection{Perception of impacts}

The perception of negative impacts from the preparations for the Olympic Games in Sochi is much more acute than those of positive ones. This result is in stark contrast to the common finding that, prior to hosting, residents tend to rate negative impacts from events lower than positive impacts (eg, Gursoy and Kendall, 2006; Kim and Petrick, 2005; Kim et al, 2006; Mihalik and Simonetta, 1999; Zhou and Ap, 2009). One reason for this situation could be the extraordinary scale of construction taking place in Sochi, which makes it hard for anyone to ignore negative impacts. The ranking of increased traffic jams and increased price levels at the top of the list of perceived costs corresponds to people's everyday experience: almost everyone who has to take any form of transport in Sochi will at some point be locked down in traffic jams. Speculation and the influx of capital from outside the region have contributed to a rise in house prices to a level where most residents of Sochi are now unable to afford anything but the most basic properties. Another reason for the prominent perception of negative impacts might be the application of a high discount factor to future benefits. Because disruptions to city life are occurring now and most benefits will result later, this requires sacrifices in the present to receive future benefits. Owing to widespread planning insecurity and political and economic instability, people in Russia tend to discount future benefits quite heavily (Wang et al, 2010), and this is a phenomenon that might be at work in this case as well.

On the side of positive impacts, the rank order of items deserves further consideration. It is notable that beneficial impacts relating to individual development-such as better education, a higher number of jobs, and personal benefit in general-were seen as absent or almost absent. On the other hand, items that referred to improvements at a general level received a rather high rating. The high rating of the perceived contribution to economic growth, for example, does not correspond with the perceived absence of new jobs for the local population. That megaevent preparations are associated with benefits for the region but not for oneself might reflect the perception of the Olympic Games as an elite, governmentsponsored event, in which ordinary people's concerns do not figure. This does not sit well with the declared inclusive approach to urban development through the Olympic Games in the framework of sustainability (Holden et al, 2008).

At the other end of the positive impact scale, the prominent position of international reputation as the item with the highest positive rating tallies with a number of other studies. Ritchie and Lyons (1990) found in an ex post study of the 1988 Olympic Games, 
for example, that about half of the residents saw image benefits, whereas only about a third mentioned economic benefits. In surveys of the 1996 Olympic Games in Atlanta and the 2008 Olympic Games in Beijing, image benefits, too, were at the top of the expected positive impacts (Gursoy et al, 2011; Mihalik and Simonetta, 1999). This high rating reflects Russia's political ambition of turning Sochi into a world-class winter resort destination. In contrast to research done in Beijing (Zhou and Ap, 2009), however, the residents in the sample showed less support and more concern about the costs of the Olympic Games, dissenting with the official line that "the preparation for the Olympic Games brings our city only positive results" (Interfax Russia 2010).

\subsection{Support and its social differentiation}

It is remarkable that, despite the strong negative evaluation of impacts, a majority of residents still support the Olympic Games in Sochi. Yet, when compared with levels of support among local residents during Sochi's Olympic bid, enthusiasm has waned considerably. In October $200686 \%$ of the population were reported to be in favour of the Olympic Games (Bidding Committee Sochi, 2006, page 45), whereas in the present survey this figure had dropped to $57 \%$. While some of this difference could be attributable to different question wording, there is still a marked decline of public support 3.5 years prior to the event. Other studies at around the same point of time before the event found that $85 \%$ (Ritchie and Aitken, 1984) or even 94\% (Mihalik and Simonetta, 1999) of the local population supported the Games. The past Winter Games in Vancouver, however, had much lower levels of support at around 60\% (Bidding Committee Vancouver, 2002, page 29; Ipsos Reid, 2005).

The level of support in Sochi varies considerably between social groups, pointing to the "differential nature of social consciousness" (Waitt, 2001, page 272) with regard to megaevents: younger residents and those with a high level of knowledge are more likely to consider hosting the Olympic Games a good idea than older residents or those with little knowledge about the preparation for the Olympic Games. The few who stated that there was public participation in the planning and preparation process also held more positive views of the Olympic Games, which is in line with hypotheses and findings from previous research (eg, Davis et al, 1988; Fredline and Faulkner, 2002; Kim and Petrick, 2005; Ritchie et al, 2009). Where the results diverge from the initial hypothesis is with regard to ethnicity: I find non-Russian residents to show even stronger support of the Olympic Games than Russians, despite allegations of exclusion and discrimination. This finding corresponds with Waitt's (2001; 2003) observation with regard to the Sydney Olympic Games that people from nonEnglish-speaking backgrounds showed higher enthusiasm than other groups. In both Sochi and Sydney the preparations for the Olympic Games have apparently been able to create a sense of place and common purpose that at least temporarily supersede ethnic friction.

\subsection{Predictors of support}

Modelling support through regression shows that if we control for perception, sociodemographic variables are only weak predictors of support. The same is true for the hypothesized moderating variables, where only knowledge has a weak positive influence on support. By far the strongest predictor is positive perception, whereas negative perception has a much weaker negative association with support (see also Deccio and Baloglu, 2002; Gursoy and Kendall, 2006). This relationship makes for a disproportionate effect of positive perceptions on support and prevents residents' strong negative perception translating into opposition to the Games. My initial hypothesis about the effect of perceptions on support has therefore been confirmed, though to differing degrees for positive and negative perceptions.

After disaggregation of the perception scales, items that refer to the symbolic dimension of the Olympic Games (image improvement, civic pride) become the strongest predictors of support, whereas the immediate infrastructural improvements (transport, energy) did not show 
significant correlations. This result underscores the status of the Olympics as a megaevent which is primarily associated with symbolic meaning production, rather than with the delivery of public services and investment (Waitt, 1999). In a second tier of significant but somewhat less strong predictors, the perception of more immediate material improvements such as personal benefit, a positive legacy, and economic growth also bolstered support. This finding corresponds with the conventional argument that communities are willing to support such events due to the positive economic benefits (eg, Getz, 2005).

On the side of negative impacts, although people in Sochi demonstrated strong concern about traffic jams, price inflation, and unequal distribution of benefits, these indicators do not feature as significant predictors. It is only perceived environmental damage, waste of public resources, and increasing crime levels that have a, however small, negative association with public support. Residents therefore tolerate some negative impacts - perhaps because they see them as inevitable — but not all.

\subsection{Policy implications}

The high explanatory value of perceived impacts for public support underscores the potential of political interventions to manage impacts for buttressing support. Whereas there will and should be intense discussion of the decision whether or not to host a megaevent, once a city has decided to act as a host, it is important that it seeks to maintain support and addresses those popular concerns that diminish it (Gursoy and Kendall, 2006, page 617). The policy implications for the Olympic authorities and the city administration resulting from this research are threefold: first, it is imperative for cities to deliver on the promises of positive impacts, while on the other hand people may be more tolerant with regard to negative impacts, some of which may be accepted as an inevitable evil. Administrations need to remain realistic, however, and should not overpromise on the benefits of events. If residents expect more positive impacts than can be delivered, this would be an irresponsible manipulation of public opinion and likely to result in a backlash, once the discrepancy between expectations and reality becomes evident. To some extent this was the case with the Olympic Games in Beijing, where public propaganda had glossed over the costs of the event and nurtured excessive expectations of benefits that were not met subsequently (Gursoy et al, 2011, pages 317-318).

The second is to ensure that the preparations for the Games reach out to as many residents as possible and not limit themselves to projects that benefit a select elite. The perception of personal benefit is a good predictor of public support, but at the moment people in Sochi do not see themselves as beneficiaries of the run-up to the Olympics. The recent emphasis on legacy planning in the Olympic Games, despite its associated challenges, is a welcome step towards leveraging spillover effects of megaevent preparation for the benefit of the general public (Andranovich and Burbank, 2011). Not only does it advocate the integration of the postevent use of facilities into the planning process from the beginning, but it also urges cities to maximize the positive impacts in a sustainable and inclusive fashion for a broad population (Holden et al, 2008). Launching initiatives at the community level that accompany large-scale construction projects should be an important component for achieving this. Such projects would ideally have community ownership to facilitate the equitable distribution of benefits and be continued after the Olympic Games to leave an enduring impact. Vancouver's 2010 LegaciesNow, an organization managing the social legacy of the 2010 Olympic Games, has been a rather successful model in this respect (Kidd, 2010).

The third implication is that prudent and transparent fiscal planning and limiting the size of expenditure would likely have a positive impact on public opinion. Given the escalating costs for the event in Sochi, this would be sound advice in any case, but experience with megaproject planning suggests that costs tend to increase over the lifetime of a project 
(Flyvbjerg, 2007). Similar attention should be given to avoiding environmental damage. In particular, during the early stages of preparation, environmental concerns were often brushed under the carpet and not incorporated into the preparation planning, and this seems to have had an effect on public opinion.

All of the above action items would, of course, be commendable for the organization of any megaevent. In reality, however, budget and time for such interventions are constrained and authorities will have to determine a few priority areas. Their role as significant predictors of public support underscores the urgency of pursuing the items above-if not for their own sake, then at least for the sake of addressing public concerns and maintaining support.

\section{Conclusion}

As hosting events is becoming ever more frequent, it is important for city and regional administrations to understand the basis and nature of public opinion towards them. This is a crucial step in taking seriously the role of the population as a major stakeholder, for whereas events often last for only a couple of days for those who attend or sponsor them, citizens experience the long phase of preparation and will have to live with whatever remains in terms of social, economic, or infrastructural legacies. The research in this paper has demonstrated the value of examining residents' perception of impacts from preparations for megaevents, since these perceptions can indeed have a sizeable effect on popular support. Carefully managing the impacts from preparations for megaevents thus constitutes a central task for administrations, not least in the interest of a smooth preparation process and successful hosting of the event itself but also for the efficient leveraging of legacies, such as social initiatives or new facilities, which are contingent on mustering public support and participation. An understanding of the perception of impacts from event preparation and the drivers of public support allows targeting interventions at the aspects of greatest concern and makes event planning more inclusive, thus reducing the likelihood of elite capture.

In Sochi participation and consultation in planning have been marginal, and public support for the event has shrunk over the past years. Despite the unprecedented investment of more than 60000 euros per inhabitant, the population perceives the negative impacts from the preparation for the Olympic Games to significantly outweigh the positive ones. This situation suggests that spending more does not per se result in more positive impacts from the viewpoint of the population, highlighting the need to better target spending. It is only because the perception of positive impacts is a much stronger predictor for support than the perception of negative impacts that a majority of the population is still in favour of hosting the event.

Notwithstanding the profound material transformation in Sochi, it is the symbolic dimension of megaevents that is most salient. While authorities often tout the stimulus effects of investment and point to the modernization of infrastructure, residents in Sochi at least perceive image benefits and increased opportunities for consumption to be the most immediate positive impacts, while immediate individual benefits rank towards the bottom. Improvement of the global image and civic pride are also the best predictors of public support for the event. These results suggest that the shift towards place promotion and the symbolic economy of consumption that scholars have observed over the past two decades in the West applies no less to postsocialist countries such as Russia, despite the rather different planning culture as well as sociopolitical context.

On a more critical note, however, the preoccupation with the symbolic and consumption dimensions of the preparation for the Olympic Games harbours the potential for social conflict. Such effects are more ephemeral than material transformations and, through their window-dressing quality, tend to divert attention from unequal appropriation and distribution 
of resources. There is the distinct risk that, once the ballyhoo subsides after the Games, residents of Sochi might find themselves in a city that still does not boast the reputation of the likes of Vail, Gstaad, and Chamonix, but has spent massive sums on specialized infrastructure, to the benefit of a select few, trying to do so. One cannot but concur with Martina Navratilova's perspicacious aphorism:

"The moment of victory is much too short to live for that and nothing else."

\section{References}

Abramson D B, 2007, "The dialectics of urban planning in China", in China's Emerging Cities: The Making of New Urbanism Ed. F Wu (Routledge, London) pp 66-86

Agureeva O, 2010, “Soči: gotovuju kvartiru v novostrojke možno kupit' za 3-4 mln rublej” [Sochi: the price for an apartment in a new building is between 3 and 4 million rubles] Tendencii June, http://www.realto.ru/journal/tendencies/show/?id=14401

Andranovich G, Burbank M J, 2011, "Contextualizing Olympic legacies" Urban Geography 32 $823-844$

Andranovich G, Burbank M J, Heying C H, 2001, "Olymic cities: lessons learned from mega-event politics" Journal of Urban Affairs 23 113-131

Ap J, 1992, "Residents' perception on tourism impacts" Annals of Tourism Research 19 665-690

Arnstein S R, 1969, "A ladder of citizen participation" Journal of the American Institute of Planners 35 216-224

Benneworth P, Dauncey H, 2010, "International urban festivals as a catalyst for governance capacity building" Environment and Planning C: Government and Policy 28 1083-1100

Berkowitz P, Gjermano G, Gomez L, Schafer G, 2007, "Brand China: using the 2008 Olympic Games to enhance China's image" Place Branding and Public Diplomacy 3 164-178

Bidding Committee Sochi, 2006 Bid Book Bidding Committee Sochi, Sochi

Bidding Committee Vancouver, 2002 Bid Book Bidding Committee Vancouver, Vancouver

Burbank M J, Heying C H, Andranovich G, 2000, "Antigrowth politics or piecemeal resistance? Citizen opposition to Olympic-related economic growth" Urban Affairs Review 35 334-357

Chalkley B, Essex S, 1999, "Urban development through hosting international events: a history of the Olympic Games" Planning Perspectives 14 369-394

City Administration of Sochi, 2011, "Bjudžet goroda Soči na 2012 god" [Budget of Sochi for the year 2012], Sochi

Conrad E, Cassar L, Christie M, Fazey I, 2011, "Hearing but not listening? A participatory assessment of public participation in planning" Environment and Planning C: Government and Policy 29 761-782

Cornelissen S, 2010, "The geopolitics of global aspiration: sport mega-events and emerging powers" International Journal of the History of Sport 27 3008-3025

Cortina J M, 1993, "What is coefficient alpha? An examination of theory and applications" Journal of Applied Psychology 78 98-104

Davis D, Allen J, Cosenza R M, 1988, "Segmenting local residents by their attitudes, interests, and opinions toward tourism" Journal of Travel Research 28 2-8

Deccio C, Baloglu S, 2002, "Nonhost community resident reactions to the 2002 Winter Olympics: the spillover impacts" Journal of Travel Research 41 46-56

Delamere T A, 2001, "Development of a scale to measure resident attitudes towards the social impact of community festivals II: verification of the scale" Event Management 7 25-38

Delamere T A, Wankel L M, Hinch T D, 2001, "Development of a scale to measure resident attitudes toward the social impacts of community festivals. Part I: item generation and purification of the measure" Event Management 7 11-24

Den'gi 2011, "Poljana gorodskogo tipa" [Poljana of an urban type] Den'gi 14 February, http://www.kommersant.ru/doc/1578255

Flyvbjerg B, 2007, "Policy and planning for large-infrastructure projects: problems, causes, cures" Environment and Planning B: Planning and Design 34 578-597

Fredline L, Faulkner B, 2002, "Residents' reactions to the staging of major motorsport events within their communities: a cluster analysis" Event Management 7 103-114 
Fredline L, Jago L, Deery M, 2003, "The development of a generic scale to measure the social impacts of events" Event Management 8 23-37

Getz D, 2005 Event Management and Event Tourism Cognizant Communication, New York

Goskomstat, 2007 Rossija v cifrax [Russia in numbers] Goskomstat, Moscow

Gotham K F, 2011, "Resisting urban spectacle: the 1984 Louisiana World Exposition and the contradictions of mega-events" Urban Studies 48 197-214

Gratton C, Shibli S, Coleman R, 2005, "Sport and economic regeneration in cities" Urban Studies 42 985-999

Gursoy D, Jurowski C, Uysal M, 2002, "Resident attitudes: a structural modelling approach" Annals of Tourism Research 29 79-105

Gursoy D, Kendall K W, 2006, "Hosting mega-events: modeling locals' support" Annals of Tourism Research 33 603-623

Gursoy D, Chi C G, Ai J, Chen B T, 2011, "Temporal change in resident perceptions of a mega-event: the Beijing 2008 Olympic Games" Tourism Geographies 13 299-324

Hall T, Hubbard P, 1996, "The entrepreneurial city: new urban politics, new urban geographies?" Progress in Human Geography 20 153-174

Häußermann H, Siebel W, 1993, "Die Politik der Festivalisierung und die Festivalisierung der Politik" Leviathan 21 7-31

Hiller H, 2000, "Mega-events, urban boosterism and growth strategies: an analysis of the legitimations of Cape Town 2004 Olympic bid" International Journal of Urban and Regional Research 24 439-458

Hiller H, Wanner R, 2011, "Public opinion in host Olympic cities: the case of the 2010 Vancouver Winter Games" Sociology 45 883-899

Holden M, MacKenzie J, VanWynsberghe R, 2008, "Vancouver's promise of the world's first sustainable Olympic Games" Environment and Planning C: Government and Policy 26 882-905

Interfax Russia 2010, "Mèr Soči Anatolij Pakhomov: 'Podgotovka k Olimpiade 2014 goda daët našemu gorodu tol'ko položitel'nye rezul'taty'" [The mayor of Sochi, Anatolij Pakhomov: 'The preparation for the Olympic Games 2014 brings only positive outcomes for our city'] Interfax Russia 21 May, http://www.interfax-russia.ru/South/exclusives. asp?id=147020

IOC, 2005 Report of the IOC Evaluation Commission for the Games of the XXX Olympiad in 2012 International Olympic Committee, Lausanne

Ipsos Reid, 2005, "Support for 2010 Olympic Games rises in British Columbia", http://www.ipsos-na.com/news-polls/pressrelease.aspx?id=2542

Keogh B, 1990, "Public participation in community tourism planning" Annals of Tourism Research $17449-465$

Kidd B, 2010, "The legacies of the 2010 Winter Olympic and Paralympic Games in Vancouver", unpublished manuscript, http://doc.rero.ch/record/22123

Kim H J, Gursoy D, Lee S-B, 2006, "The impact of the 2002 World Cup on South Korea: comparisons of pre- and post-games" Tourism Management 27 86-96

Kim S S, Petrick J F, 2005, "Residents' perceptions on impacts of the FIFA 2002 World Cup: the case of Seoul as a host city" Tourism Management 26 25-38

Klimov I, 2010, "Skrytye linii social'nych razlomov v predolimpijskom Soči” [Hidden social fault lines in pre-Olympic Sochi] Monitoring obščestvennogo mnenija 97 163-172

Kokx A, van Kempen R, 2010, "A fact is a fact, but perception is reality: stakeholders' perceptions and urban policies in the process of urban restructuring" Environment and Planning C: Government and Policy 28 335-348

Lankford S V, Howard D, 1994, "Developing a tourism impact attitude scale" Annals of Tourism Research 21 121-139

Lash S, Urry J, 1994 Economies of Signs and Space (Sage, London)

Lenskyj H, 2002 The Best Olympics Ever? Social Impacts of Sydney 2000 (SUNY Press, Albany, NY)

Lenskyj H, 2008 Olympic Industry Resistance: Challenging Olympic Power and Propaganda (SUNY Press, Albany, NY)

Light M, 2010, "Sochi and northwest Caucasus II", http://globalbrief.ca/blog/2010/04/12/sochi-and-the-northwest-caucasus-\%E2\%80\%93-ii/ 
Lorde T, Greenidge D, Devonish D, 2011, "Local residents' perceptions of the impacts of the ICC Cricket World Cup 2007 on Barbados: comparisons of pre- and post-games" Tourism Management 32 349-356

MacRury I, Poynter G, 2008, "The regeneration Games: commodities, gifts and the economics of London 2012" The International Journal of the History of Sport 25 2072-2090

Matheson V, 2008, "Mega-events: the effect of the world's biggest sporting events on local, regional, and national economies", in The Business of Sports Eds D Howard, B Humphrey (Praeger, Westport, CT) pp 81-99

Mihalik B J, Simonetta L, 1999, “A midterm assessment of the host population's perceptions of the 1996 Summer Olympic Games: support, attendance, benefits, and liabilities” Journal of Travel Research 37 244-248

Müller M, 2011, "State dirigisme in megaprojects: governing the 2014 Winter Olympics in Sochi" Environment and Planning A 43 2091-2108

Newman P, 2007, " 'Back the bid': the 2012 Summer Olympics and the governance of London" Journal of Urban Affairs 29 255-267

Novaja Gazeta 2009, “Olimpijskij zator” [Olympic traffic jam] 5 August, http://www.novayagazeta.ru/society/44081.html

Nunnaly J, 1978 Psychometric Theory (McGraw-Hill, New York)

O'Bonsawin C, 2010, "No Olympics on stolen native land: contesting Olympic narratives and asserting indigenous rights within the discourse of the 2010 Vancouver Games" Sport in Society $13143-156$

OECD, 2001 Citizens as Partners: OECD Handbook on Information, Consultation and Public Participation in Policy-making (OECD, Paris)

Ogonëk 2010, "Poljana pritjaženija" [Poljana of attraction] 1 March , http://www.kommersant.ru/doc/1327075

Paddison R, 1993, "City marketing: image reconstruction and urban regeneration" Urban Studies $30339-350$

Ponsford I F, Williams P, 2010, "Crafting a social license to operate: a case study of Vancouver 2010's Cypress Olympic venue" Event Management 14 17-36

Preuss H, 2004, "Calculating the economic impact of the Olympic Games" European Sport Management Quarterly 4 234-253

Putin V V, 2007, "Speech at the 119th International Olympic Committee session", Guatemala, 4 July, http://archive.kremlin.ru/eng/text/speeches/2007/07/04/2103_ type82912type84779type127286_136956.shtml

Richards G, 2007, "The festivalization of society or the socialization of festivals? The case of Catalunya", in Cultural Tourism: Global and Local Perspectives Ed. G Richards (Haworth Hospitality Press, Binghamton, NY) pp 257-280

Richards G, Wilson J, 2004, "The impact of cultural events on city image: Rotterdam, cultural capital of Europe 2001" Urban Studies 41 1931-1951

Ritchie B W, Shipway R, Cleeve B, 2009, "Resident perceptions of mega-sporting events: a non-host city perspective of the 2012 London Olympic Games" Journal of Sport and Tourism 14 143-167

Ritchie J R B, Aitken C E, 1984, "Assessing the impacts of the 1988 Olympic Winter Games: the research program and initial results" Journal of Travel Research 22 17-25

Ritchie J R B, Lyons M, 1990, "Olympulse VI: a post-event assessment of resident reaction to the XV Olympic Winter Games” Journal of Travel Research 28 14-23

Ritchie J R B, Smith B H, 1991, "The impact of a mega-event on host region awareness: a longitudinal study" Journal of Travel Research 30 3-10

Roche M, 2000 Mega-events and Modernity (Routledge, London)

Roux A-C, 2010 Le débat autour de la préparation des Jeux Olympiques d'hiver de Sochi 2014: environnement et politique en Russie aujourd'hui [The debate around the preparation for the 2014 Winter Olympic Games in Sochi: environment and politics in Russia today] Ecole des Hautes Etudes en Sciences Sociales, Paris

Scharr K, Steinicke E, 2010, “Trouble in paradise: Olympische Winterspiele in Sochi 2014" Osteuropa 60(8) 47-61 
Simmons D G, 1994, "Community participation in tourism planning” Tourism Management 15 98-108

Smith A, 2005a, "Reimagining the city: the value of sport initiatives" Annals of Tourism Research 32 229-248

Smith A, 2005b, "Conceptualizing image change: the reimagining of Barcelona" Tourism Geographies $7398-423$

Smith A, Fox T, 2007, "From 'event-led' to 'event-themed' regeneration: the 2002 Commonwealth Games legacy programme" Urban Studies 44 1125-1143

Stanilov K, 2007, "Urban planning and the challenges of post-socialist transformation", in The Postsocialist City: Urban Form and Space Transformations in Central and Eastern Europe after Socialism Ed. K Stanilov (Springer, Dordrecht) pp 413-425

Thomas W I, Thomas D S, 1928 The Child in America: Behavior Problems and Programs (Knopf, New York)

Vanolo A, 2008, "The image of the creative city: some reflections on urban branding in Turin" Cities $25370-382$

Vlast 2008, "24 tys. rub. s každogo nelegala v god" [24 thousand roubles from every person per year] 10 March, http://www.kommersant.ru/doc/864889

Vrijaldenhoven T v, 2007 Reaching Beyond the Gold: The Impact of Global Events on Urban Development (010 Publishers, Rotterdam)

Waitt G, 1999, "Playing games with Sydney: marketing Sydney for the 2000 Olympics" Urban Studies 36 1055-1077

Waitt G, 2001, "The Olympic spirit and civic boosterism: the Sydney 2000 Olympics" Tourism Geographies 3 249-278

Waitt G, 2003, "Social impacts of the Sydney Olympics" Annals of Tourism Research 30 194-215

Wang M, Rieger M O, Hens T, 2010, "How time preferences differ: evidence from 45 countries", WP9, Sante Fe Institute, NM

Wang T H, 2006, "Trading the people's homes for the people's Olympics: the property regime in China" Pacific Rim Law and Policy Journal 15 599-626

Zhang L, Zhao S X, 2009, "City branding and the Olympic effect: a case study of Beijing" Cities $26245-254$

Zhou Y, Ap R, 2009, “Residents' perceptions towards the impacts of the Beijing 2008 Olympic Games" Journal of Travel Research 48 78-91 